\title{
Die invloed van verdamping op die segregasieproses
}

\begin{tabular}{|c|c|}
\hline $\begin{array}{l}\text { Authors: } \\
\text { Shaun Cronjé } \\
\text { W.D. Roos }{ }^{1} \\
\text { R.E. Kroon }{ }^{1} \\
\text { J.K.O. Asante }\end{array}$ & \\
\hline \multicolumn{2}{|c|}{$\begin{array}{l}\text { Affiliations: } \\
{ }^{1} \text { Department of Physics, } \\
\text { University of the Free State, } \\
\text { South Africa }\end{array}$} \\
\hline \multicolumn{2}{|c|}{$\begin{array}{l}{ }^{2} \text { Department of Physics, } \\
\text { Tshwane University of } \\
\text { Technology, South Africa }\end{array}$} \\
\hline \multicolumn{2}{|c|}{$\begin{array}{l}\text { Correspondence to: } \\
\text { Shaun Cronjé }\end{array}$} \\
\hline \multicolumn{2}{|c|}{$\begin{array}{l}\text { Email: } \\
\text { cronjes@ufs.ac.za }\end{array}$} \\
\hline \multicolumn{2}{|c|}{$\begin{array}{l}\text { Postal address: } \\
\text { PO Box 339, Bloemfontein } \\
\text { 9300, South Africa }\end{array}$} \\
\hline \multicolumn{2}{|c|}{$\begin{array}{l}\text { How to cite this abstract: } \\
\text { Cronjé, S., Roos, W.D., Kroon, } \\
\text { R.E. \& Asante, J.K.O., 2013, } \\
\text { 'Die invloed van verdamping } \\
\text { op die segregasieproses', } \\
\text { Suid-Afrikaanse Tydskrif } \\
\text { vir Natuurwetenskap en } \\
\text { Tegnologie 32(1), Art. } \\
\text { \#407, } 1 \text { page. http://dx.doi. } \\
\text { org/10.4102/satnt.v32i1.407 }\end{array}$} \\
\hline \multicolumn{2}{|c|}{$\begin{array}{l}\text { Note: } \\
\text { This abstract was presented } \\
\text { at the 'Studentesimposium } \\
\text { in die Natuurwetenskappe } \\
2011 \text { ', presented under } \\
\text { the protection of the Suid- } \\
\text { Afrikaanse Akademie vir } \\
\text { Wetenskap en Kuns. The } \\
\text { symposium was held at the } \\
\text { University of South Africa on } \\
\text { 27-28 October } 2011 \text {. }\end{array}$} \\
\hline \multicolumn{2}{|c|}{$\begin{array}{l}\text { Copyright: } \\
\text { (C) 2013. The Authors. } \\
\text { Licensee: AOSIS } \\
\text { OpenJournals. This wc } \\
\text { is licensed under the } \\
\text { Creative Commons } \\
\text { Attribution License. }\end{array}$} \\
\hline \multicolumn{2}{|l|}{ Read online: } \\
\hline 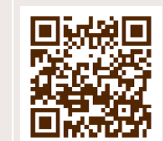 & $\begin{array}{l}\text { Scan this QR } \\
\text { code with your } \\
\text { smart phone or } \\
\text { mobile device } \\
\text { to read online. }\end{array}$ \\
\hline
\end{tabular}

Measuring the effect of surface evaporation on the segregation process. Metallurgical products play an important role in everyday life. One process, by means of which metallurgical properties can be determined, is known as segregation. The influence of surface evaporation should be considered in order to improve segregation studies. Modifications made to an Auger system in order to measure surface evaporation that takes place during segregation are discussed.

Metallurgiese produkte speel 'n belangrike rol in die alledaagse lewe. Die soektog na legerings met beter meganiese eienskappe soos groter treksterkte asook slytasie- en korrosieweerstand duur steeds voort. Bo en behalwe hierdie eienskappe, soek wetenskaplikes ook na maniere om die produksiekoste en -tyd van veral katalisatore te verlaag en te verkort. Een van die potensiële prosesse om dit te bewerkstellig, staan as segregasie bekend.

Daar bestaan reeds verskeie segregasiemodelle wat die oppervlakkonsentrasie van die segregerende spesie as 'n funksie van tyd en temperatuur kan beskryf. Hierdie modelle neem egter nie die verdamping of sublimasie van die segregerende spesie in ag nie. Eksperimentele segregasiestudies vind gewoonlik in 'n ultrahoë vakuum plaas, wat die kans op verdamping aansienlik verhoog.

Alhoewel pogings aangewend is om segregasiemodelle wat verdamping in ag neem te ontwikkel, voorspel hierdie modelle die segregasiegedrag in òf die konsentrasiekinetika òf die konsentrasie-ewewigsgebiede. Daarbenewens is die invloed van verdamping in vroeëre eksperimentele studies gerieflikheidshalwe geïgnoreer. In hierdie ondersoek is die verdamping van $\mathrm{Sb}$ van 'n Cu-oppervlak tydens segregasie in 'n Cu (110) $0.2 \%$ Sb gemeet. Die resultate sal tesame met 'n gewysigde Darkenmodel gebruik word om die segregasieprofiel, insluitende die gevolge van verdamping, te voorspel. 'n Eersteordebenadering tot die model, asook die veranderinge wat aan die manipulator van 'n Augerelektronspektroskopie-spektrometer aangebring is ten einde die verdampingsinvloed te kwantifiseer, sal bespreek word. 